\section{Successful Desensitization to Etoposide in a Preschool Pediatric Patient}

Kulhas Celik I ${ }^{1}$, Guvenir $\mathrm{H}^{1}$, Buyuktiryaki B ${ }^{1}$, Dibek Misirlioglu E ${ }^{1}$, Ozyoruk D ${ }^{2}$, Toyran $\mathrm{M}^{1}$

${ }^{1}$ University of Health Sciences, Ankara Child Health and Diseases Hematology Oncology Training and Research Hospital, Division of Pediatric Allergy and Immunology, Ankara, Turkey

${ }^{2}$ University of Health Sciences, Ankara Child Health and Diseases

Hematology Oncology Training and Research Hospital, Division of Pediatric Hematology Oncology, Ankara, Turkey

J Investig Allergol Clin Immunol 2018; Vol. 28(5): 363-364 doi: 10.18176/jiaci.0292

Key words: Anaphylaxis. Desensitization. Etoposide.

Palabras clave: Anafilaxia. Desensibilización. Etopósido.

Etoposide is derivative of podophyllin and acts by inhibiting mitosis. It is a chemotherapeutic agent that has been used in the treatment of numerous malignant neoplasms [1]. Intravenous etoposide is generally well tolerated. It is reported to induce hypersensitivity reactions (HSRs) in up to $6 \%$ of patients, although the incidence of anaphylaxis is low $(0.7 \%)$ [2]. Solvent in intravenous etoposide preparations has been proposed as the culprit of the reactions, although there have been reports of recurrent reactions despite use of etoposide phosphate, which does not contain polysorbate $80[3,4]$.

We report the case of a 2.5-year-old boy diagnosed with retinoblastoma in our pediatric oncology clinic who experienced a hypersensitivity reaction to intravenous etoposide. He tolerated the first infusion without premedication. Twenty-one days later, the second dose was started without premedication. After 10 minutes, he experienced generalized urticaria, palpebral and labial angioedema, and shortness of breath. He also had cyanotic lips. He was found to be hypotensive (blood pressure, $60 / 30 \mathrm{mmHg}$ ) and desaturated to $80 \%$ on pulse oximetry. The infusion was interrupted immediately, and we administered intramuscular adrenaline $0.01 \mathrm{mg} / \mathrm{kg}$, hydroxyzine $1 \mathrm{mg} / \mathrm{kg}$, and prednisolone $1 \mathrm{mg} / \mathrm{kg}$. Symptoms improved within 1 hour. The patient was referred to our allergy clinic for evaluation. Skin tests with etoposide were performed. Prick testing $(20 \mathrm{mg} / \mathrm{mL})$ and intradermal testing ( $2 \mathrm{mg} / \mathrm{mL}$ ) were negative. Etoposide is considered to be a critical component of an effective treatment of retinoblastoma. Thus, in this case, continued use of etoposide was warranted. We decided to apply desensitization. The etoposide phosphate preparation without polysorbate 80 could not be used because it was not available.

The desensitization protocol involved calculation of the total dose of etoposide in order to prepare 3 different dilutions (dilution A, $0.002 \mathrm{mg} / \mathrm{mL}$; dilution $\mathrm{B}, 0.02 \mathrm{mg} / \mathrm{mL}$; and dilution $\mathrm{C}, 0.2 \mathrm{mg} / \mathrm{mL}$ ) (Table). We used a modified version of the protocol developed by Castells et al [5]. The 12-step desensitization protocol, with 4 steps for each solution, was completed in 4 hours (Table). The infusion was initiated 1 hour after the administration of oral hydroxyzine $1 \mathrm{mg} / \mathrm{kg}$ and intravenous methylprednisolone $1 \mathrm{mg} / \mathrm{kg}$. In addition, oral paracetamol $10 \mathrm{mg} / \mathrm{kg}$ was administered prior to infusion because the patient had fever, not as premedication.

Garcia Escallon et al [6] reported on a 14-step, 15-hour protocol starting with premedication (diphenhydramine, ondansetron, epinephrine, heparin, dexamethasone) in a 79-year-old patient. Gómez-Duque et al [7] subsequently performed a 10-step protocol lasting 3 hours and 25 minutes in a 63 -year-old patient. The authors gave the patient $8 \mathrm{mg}$

Table. Intravenous Desensitization Protocol for Etoposide

\begin{tabular}{|c|c|c|c|c|c|c|}
\hline Step & Solution Type ${ }^{a}$ & Rate, $\mathrm{mL} / \mathrm{h}$ & $\begin{array}{l}\text { Infusion Duration, } \\
\text { min }\end{array}$ & $\begin{array}{l}\text { Volume Infused } \\
\text { per Step, mL }\end{array}$ & $\begin{array}{l}\text { Dose Administered } \\
\text { With This Step, mg }\end{array}$ & $\begin{array}{c}\text { Cumulative Dose, } \\
\text { mg }\end{array}$ \\
\hline 1 & A & 8 & 15 & 2 & 0.004 & 0.004 \\
\hline 2 & A & 16 & 15 & 4 & 0.008 & 0.012 \\
\hline 3 & A & 32 & 15 & 8 & 0.016 & 0.028 \\
\hline 4 & A & 64 & 15 & 16 & 0.032 & 0.06 \\
\hline 5 & B & 16 & 15 & 4 & 0.08 & 0.14 \\
\hline 6 & B & 32 & 15 & 8 & 0.16 & 0.3 \\
\hline 7 & B & 64 & 15 & 16 & 0.32 & 0.62 \\
\hline 8 & B & 128 & 15 & 32 & 0.64 & 1.26 \\
\hline 9 & $\mathrm{C}$ & 32 & 15 & 8 & 1.6 & 2.86 \\
\hline 10 & $\mathrm{C}$ & 64 & 15 & 16 & 3.2 & 6.06 \\
\hline 11 & $\mathrm{C}$ & 128 & 15 & 32 & 6.4 & 12.46 \\
\hline 12 & $\mathrm{C}$ & 211 & 75 & 263.75 & 52.75 & 65 \\
\hline
\end{tabular}

a Solution $\mathrm{A}$ is $10 \mathrm{~mL}$ of B solution $+90 \mathrm{~mL}$ of $0.9 \% \mathrm{NaCl}$ (concentration, $0.002 \mathrm{mg} / \mathrm{mL}$ ). Solution B is $2 \mathrm{mg}$ of drug $+100 \mathrm{~mL}$ of $0.9 \% \mathrm{NaCl}$ (concentration, $0.02 \mathrm{mg} / \mathrm{mL}$ ). Solution $\mathrm{C}$ is $80 \mathrm{mg}$ of drug $+396 \mathrm{~mL}$ of $0.9 \% \mathrm{NaCl}$ (concentration, $0.2 \mathrm{mg} / \mathrm{mL}$ ). 
dexamethasone before desensitization in order to prevent vomiting. The only protocol used for children was a 15-step protocol performed in an 8-year-old girl. The authors initially planned a 12-step protocol and prepared 3 solutions resembling the dilutions we prepared; however, the child had a reaction during the first attempt, prompting them to add a further 3 steps lasting 9 hours [8].

We administered the drug using a 12-step protocol lasting 4 hours and recorded no reaction. We administered premedication before the first dose, although monthly desensitizations were subsequently performed without premedication. Based on this desensitization protocol, the patient has continued therapy with etoposide every 4 weeks without complications. To date, he has received etoposide 4 times with no adverse reactions.

To the best of our knowledge, this is the first report of a successful desensitization protocol with etoposide in the preschool age group.

\section{Funding}

The authors declare that no funding was received for the present study.

\section{Conflicts of Interest}

The authors declare that they have no conflicts of interest.

\section{References}

1. Cortijo-Cascajares S, Jiménez-Cerezo MJ, Herreros de Tejada A: Review of hypersensitivity reactions to antineoplastic agents. Farm Hosp. 2012;36:148-58.

2. Lee $C$, Gianos M, Klaustermeyer WB. Diagnosis and management of hypersensitivity reactions related to common cancer chemotherapy agents. Ann Allergy Asthma Immunol. 2009; 102:179-87.
3. Collier K, Schink C, Young AM, How K, Seckl M, Savage P. Successful treatment with etoposide phosphate in patients with previous etoposide hypersensitivity. J Oncol Pharm Pract. 2008; $14: 51-5$

4. Sambasivan K, Mahmoud S, Kokache A, Seckl M, Savage P. Hypersensitivity reactions to etoposide phosphate. J Oncol Pharm Pract. 2014;20:158-60.

5. Castells M, Sancho-Serra M, Simarro M. Hypersensitivity to antineoplastic agents: mechanisms and treatment with rapid desensitization. Cancer Immunol Immunother. 2012;61:157584.

6. Garcia Escallon S, Muniyappa PK, Subramanian S. Successful rapid desensitization to intravenous etoposide using a 14-step protocol. J Allergy Clin Immunol Pract. 2015 JulAug;3(4):627-8.

7. Gómez-Duque $M$, Sala-Cunill A, Farriols $A$, Cardona V, Luengo O. Safe and Time-Saving Desensitization Protocol to Intravenous Etoposide. J Allergy Clin Immunol Pract. 2016 JulAug;4(4):793-4.

8. Alvarez Cardona A, Hernández Nieto L, Pérez Gómez $M$, Pedroza Meléndez A, Huerta López JG. Desensibilizacion para etoposido. Comunicacion de un caso. Rev Alerg Mex. 2010 Jan-Feb;57(1):33-6.

Manuscript received February 23, 2018; accepted for publication July 10, 2018.

Ilknur Kulhas Celik

University of Health Sciences

Ankara Child Health and Diseases Hematology Oncology

Training and Research Hospital Division of Pediatric Allergy and Immunology

Ankara, Turkey

E-mail: dr.ilknur-46@windowslive.com 